Holmberg, C. G. \& Laurell, C.-B. (I948). Acta chem. scand. 2, 550.

Lahey, M. E., Gubler, C. J., Chase, M. S., Cartwright, G. E. \& Wintrobe, M. M. (1952). Blood, 7,1053 .

Marston, H. R. (1952). Physiol. Rev. 32, 66.

Pálsson, P. A. \& Grimsson, H. (1953). Proc. Soc. exp. Biol., N.Y., 83, 518.

Percival, T. (1 785$)$. Med. Trans. Coll. Phys. 3, 80.

Playoust, M. R. \& Dale, N. E. (196I). Metabolism, 10, 304.

Popper, H. (1961). In Wilson's Disease: Some Current Concepts, p. 192. [J. M. Walshe and J. N. Cumings, editors.] Oxford: Blackwell Scientific Publications.

Richterich, R. (1961). In Wilson's Disease: Some Current Concepts, p. 81. [J. M. Walshe and J. N. Cumings, editors.] Oxford: Blackwell Scientific Publications.

Rosenoer, V. M. \& Michell, R. C. (I959). Brit. F. Radiol. 32, 805.

Ryś, R. (1959). Nature, Lond., $\mathbf{x 8 3}, 1596$.

Uriel, J., Götz, H. \& Grabar, P. (1957). Schweiz. med. Wschr. Suppl. r4, 43 r.

Van Wyk, J. J., Baxter, J. H., Akeroyd, J. H. \& Motulsky, A. G. (I953). Fohns Hopk. Hosp. Bull. 93, 41.

Walshe, J. M. (1956). Lancet, 270, 25.

Wilson, J. F. \& Iahey, M. E. (1960). Pediatrics, Springfield, 25, 40.

Wintrobe, M. M., Cartwright, G. E., Hodges, R. E., Gubler, C. J., Mahoney, J. P., Daum, K. \& Bean, W. B. (1954). Trans. Ass. Amer. Phycns, 67, 232.

Zimdahl, W. T., Hyman, I. \& Cook, E. D. (1953). Neurology, 3, 569.

\title{
Chronic magnesium deficiency
}

\section{By Paul Fourman and D. B. Morgan, Medical Unit, Royal Infirmary, Cardiff}

Magnesium deficiency has only rarely been recognized in man and the criteria for its diagnosis are not established (Anonymous, 1960). Most reports so far have been based on the finding of a low serum $\mathrm{Mg}$ content. The patients fall in three groups:

(I) The first includes patients with a low serum $\mathrm{Mg}$ content for which no satisfactory explanation can be produced. Miller (1944) described tetany in a child with a low plasma Mg content. Flink, Stutzman, Anderson, Konig \& Fraser (1954) claimed that $\mathrm{Mg}$ deficiency could complicate chronic alcoholism and even explain delirium tremens. These observations were not satisfactorily controlled (Clough, I960) but recent reports from the same laboratory show that patients with alcoholism, cirrhosis and malnutrition may have a Mg deficiency (McCollister, Flink \& Doe, I960). There is, however, no satisfactory evidence to show that this deficiency produced delirium tremens. Other authors have described patients with an unexplained low serum $\mathrm{Mg}$ content (Hirschfelder \& Haury, I934; Suter \& Klingman, I955; Randall, Rossmeisl \& Bleifer, I 959). More recently it has become obvious that an excessive secretion of aldosterone (Hanna \& MacIntyre, I960) should be considered as a possible factor.

(2) The second group comprises patients who had been losing intestinal fluids while maintained with fluids given parenterally which did not contain $\mathrm{Mg}$. The intestinal secretions normally contain less than 3 m-equiv. $\mathrm{Mg} / \mathrm{l}$. (Nicolaysen, I936), therefore losses must continue for several weeks before a serious deficit can arise (Flink, McCollister, Prasad, Melby \& Doe, I957; Hammarsten \& Smith, 1957; Card \& Marks, I958; Randall et al. I959; Vallee, Wacker \& Ulmer, I960; Baron, I960; Cope \& Barnes, I960).

(3) The third group consists of patients with intestinal malabsorption. Calcium deficiency has long been recognized in steatorrhoea and since the chemical properties of $\mathrm{Mg}$ are very close to those of calcium, steatorrhoea might be expected to produce 
deficiencies of Mg too. Tibbetts \& Aub (1937), however, in a classic work found that their patient absorbed $\mathrm{Mg}$ normally, and perhaps because of this observation little interest was shown in the problem in the intervening years. Quite recently Fletcher, Henly, Sammons \& Squire (1960) and Hanna, Harrison, MacIntyre \& Fraser (1960) have described $\mathrm{Mg}$ deficiency complicating steatorrhoea. The two patients both had a low plasma Mg content. They had few symptoms other than weakness and our present concept of the clinical syndrome of $\mathrm{Mg}$ deficiency is based on patients in the second group. Apart from weakness the main symptoms are nervous and may be classed as cortical, extrapyramidal and peripheral. The cortical symptoms are those of an organic dementia; several authors have emphasized irritability and aggressiveness. The extrapyramidal symptoms consist of involuntary athetoid movements and tremors. The peripheral nerves are abnormally excitable and there may be tetany (Vallee et al. r960). Certain observations, however, lead one to doubt whether tetany can be the result of uncomplicated deficiency of $\mathrm{Mg}$. Thus, when $\mathrm{Mg}$ is withdrawn from the extracellular fluid of dogs by extracorporeal dialysis the animals do not have tetany (Grantham, $\mathrm{Tu} \&$ Schloerb, 1960). Vallee et al. (1960) emphasized that tetany in their patients could be abolished with $\mathrm{Mg}$ alone, but this does not in any way settle the problem since $\mathrm{Mg}$ has the pharmacological effect of diminishing neuromuscular irritability (Frankenhaeuser \& Meves, I958) and tetany from calcium deficiency can be abolished with $\mathrm{Mg}$ (Eliel, Smith \& Thomsen, I960).

The total deficit of $\mathrm{Mg}$ has been assessed only once by Card \& Marks (1958). Their patient became extremely ill after losing daily 5 l. of intestinal fluids for over a month. The patient, a woman, was small and the calculated deficit, 340 m-equiv., must have represented about a quarter of her normal $\mathrm{Mg}$ store.

\section{The investigation}

Our own observations concern four patients with steatorrhoea, who had a normal plasma $\mathrm{Mg}$ content and no symptoms of $\mathrm{Mg}$ deficiency. We studied the effect of giving them $\mathrm{Mg}$ parenterally, which normally is fairly rapidly excreted in the urine but not in the faeces (Table I).

Table $\mathrm{I}$. Urinary and faecal excretion of injected magnesium by different species

\begin{tabular}{|c|c|c|c|c|c|c|c|c|}
\hline \multirow[b]{2}{*}{ Reference } & \multirow[b]{2}{*}{ Species } & \multirow{2}{*}{$\begin{array}{l}\text { No. } \\
\text { examined }\end{array}$} & \multicolumn{2}{|c|}{$\mathrm{Mg}$ injected } & \multicolumn{4}{|c|}{ Urinary $\mathrm{Mg}$ (as } \\
\hline & & & (m-equiv.) & Salt & Route & Period & dose injected) & Faecal Mg \\
\hline $\begin{array}{l}\text { Mendel \& } \\
\quad \text { Benedict (1909) }\end{array}$ & Dog & 13 & I 4 & Sulphate & $\mathrm{SC}$ & $48 \mathrm{~h}$ & $62-72$ & No increase \\
\hline Nicolaysen (1936) & Dog & 2 & 12 & Sulphate & $\mathrm{SC}$ & $72 \mathrm{~h}$ & 74,82 & No increase \\
\hline $\begin{array}{l}\text { Smith, Winkler \& } \\
\text { Schwartz (1939) }\end{array}$ & Dog & 5 & $5^{0-77}$ & Sulphate & IV & $24 \mathrm{~h}$ & $50-88$ & No increase \\
\hline $\begin{array}{l}\text { McCance \& } \\
\text { Widdowson (1939) }\end{array}$ & Man & 6 & 255 & Gluconate & IV & I4 days & 100 & No increase \\
\hline Pritchard (1955) & Man & 2 & 33 & Sulphate & IV & $24 \mathrm{~h}$ & 99 & \\
\hline $\begin{array}{l}\text { FitzGerald \& } \\
\quad \text { Fourman (1956) }\end{array}$ & Man & 2 & 49,82 & Sulphate & IV & 3 days & 94,100 & \\
\hline Womersley (I958) & Man & 2 & 70 & Lactate & IV & $24 \mathrm{~h}$ & 100 & \\
\hline Smith $(1959 a, b)$ & $O x$ (calf) & 2 & 83 & Sulphate & $\mathrm{SC}$ & & & No increase \\
\hline $\begin{array}{l}\text { McCollister et al. } \\
\quad(1960)\end{array}$ & Man & 2 & 48,96 & Sulphate & IM & 6 days & 92,90 & \\
\hline
\end{tabular}




\section{Procedures}

Intravenous infusions. The urinary excretion of $\mathrm{Mg}$ was measured during and after the infusion of $84 \mathrm{~m}$-equiv. $\mathrm{Mg}$ as the sulphate and as the chloride. The infusions were given at a constant rate of 1 l. isotonic dextrose solution, and lasted $6 \mathrm{~h}$. Control observations were made on two medical students and on one woman aged 34 with asthma.

Repeated intravenous injections. The urinary excretion of $\mathrm{Mg}$ was measured daily while the patients received injections of $42 \mathrm{~m}$-equiv. $\mathrm{MgSO}_{4}$ daily or on alternate days, for a number of weeks (see Fig. 3). We were thus able to estimate the total amount of $\mathrm{Mg}$ retained.

\section{Methods}

The methods used for the determination of $\mathrm{Mg}$, calcium and creatinine were: $\mathrm{Mg}$ in urine, Garner (1946); in plasma, Wilkinson (r960); Ca, Fales \& Paubionsky (1958); creatinine, Kingsley, Schaffert \& Reiner (I953).

\section{Patients}

Patient no. I (J.R.), a man born in I902, had attacks of abdominal pain and fatty diarrhoea since 1959. He complained of weakness which was at first attributed to anaemia, and subsequently of failing vision caused by cataracts. Early in I960 he began to have tetany. At this time his plasma Ca was $8.5 \mathrm{mg} / 100 \mathrm{ml}$; plasma proteins, total, were $5.8 \mathrm{~g} / 100 \mathrm{ml}$ and albumin was $3.4 \mathrm{~g} / 100 \mathrm{ml}$. There was no $\mathrm{Ca}$ in the urine by the Sulkowitch test (Barney \& Sulkowitch, 1937). The bones of the spine and pelvis were radiologically less dense than normal but there were no pseudo-fractures and a biopsy of the costochondral junction showed no evidence of osteomalacia. Between January 1960 and his admission to hospital in December I 960 , his plasma $\mathrm{Ca}$ fell from 8.5 to $4.0 \mathrm{mg} / 100 \mathrm{ml}$ and then fluctuated between 4.0 and $5.5 \mathrm{mg} / 100 \mathrm{ml}$. Parathyroid extract (Eli Lilly \& Co.), $5 \mathrm{ml}$ daily for 7 days, did not increase the plasma Ca content. Vitamin D, ro 000 units parenterally (two doses), also had no effect. During his admission he had many attacks of carpopedal spasm which were always relieved by the injections of $\mathrm{Mg}$. In December 1960 the plasma $\mathrm{Mg}$ was $2.0 \mathrm{mg} / \mathrm{r} 00 \mathrm{ml}$.

Patient no. 2 (R.B.) a man born in 1920 , began to have fatty diarthoea in 1955 , with occasional abdominal colic. In 1959 he began to have tetany and later in the same year he had pain low in the back. His plasma Ca was then $7.8 \mathrm{mg} / 100 \mathrm{ml}$, his plasma inorganic $\mathrm{P} 2.2 \mathrm{mg} / \mathrm{r} 00 \mathrm{ml}$ and the serum alkaline phosphatase was 25.4 King-Armstrong units (King \& Armstrong, r934) per $100 \mathrm{ml}$. The total serum proteins were $7.1 \mathrm{~g} / 100 \mathrm{ml}$ and the serum albumin was $5.3 \mathrm{~g} / 100 \mathrm{ml}$. The bones were radiologically less dense than normal, but there were no pseudo-fractures and a bone biopsy from the iliac crest did not reveal osteoid tissue. With a gluten-free diet and calcium citrate, $20 \mathrm{~g} /$ day (equivalent to $4 \mathrm{~g} \mathrm{Ca} /$ day), the tetany ceased and the diarrhoea improved. During the 9 weeks of his stay in hospital, March to May $196 \mathrm{I}$, the plasma Ca varied between $7 \cdot 7$ and $9.2 \mathrm{mg} / 100 \mathrm{ml}$. When we began our investigations the plasma $\mathrm{Mg}$ was $1.9 \mathrm{mg} / 100 \mathrm{ml}$. 
Patient no. 3 (A.P.) a man born in 1904 , had in 1959 an extensive intestinal infarction from an embolism of the superior mesenteric artery. At operation all the small intestine was resected apart from $\mathrm{I} 2$ in. of jejunum and 4 in. of ileum. He became very weak and had fatty diarrhoea. Three months after the operation he complained of pins and needles and cramps in the legs, but these symptoms lasted only a month. The bones were radiologically normal. When we began our investigations the plasma Ca was $9.0 \mathrm{mg} / 100 \mathrm{ml}$ and the plasma $\mathrm{Mg} \mathrm{I} \cdot 65 \mathrm{mg} / 100 \mathrm{ml}$.

Patient no. 4 (G.S.), a woman born in I94I, first had fatty diarrhoea in 1957 . In I 959 she complained of severe weakness and tiredness. Her haemoglobin was $8 \mathrm{~g} / \mathrm{I} 00 \mathrm{ml}$ and she improved after a blood transfusion. There were no symptoms of tetany and her plasma $\mathrm{Ca}$ was $9.5 \mathrm{mg} / 100 \mathrm{ml}$, and the inorganic $\mathrm{P} 4.9 \mathrm{mg} / 100 \mathrm{ml}$. With a gluten-free diet the diarrhoea improved, but she failed to adhere to the diet. By February 196r she was again very weak. The bones of the pelvis and spine were radiologically less dense than normal; there were no pseudo-fractures. A biopsy from the iliac crest did not reveal osteoid tissue. During the I I weeks of investigation the plasma Ca varied between 6.9 and $8.8 \mathrm{mg} / \mathrm{r} 00 \mathrm{ml}$. Her plasma $\mathrm{Mg}$ on admission was $2.0 \mathrm{mg} / 100 \mathrm{ml}$.

Four weeks after admission she had tetany; her plasma $\mathrm{Ca}$ was then $7.9 \mathrm{mg} / \mathrm{I} 00$ $\mathrm{ml}$. The tetany responded to injections of $\mathrm{Mg}$.

\section{Results}

Intravenous infusions. Table 2 shows the urinary excretion of $\mathrm{Mg}$ in three normal persons, 24 and $48 \mathrm{~h}$ after an infusion of $\mathrm{Mg}$, and Table 3 shows the corresponding values for patients with steatorrhoea.

Table 2. Urinary excretion of magnesium by three normal persons in the 24 and $48 \mathrm{~h}$ after an infusion of $8_{4}$ m-equiv. $\mathrm{Mg}$ as $\mathrm{MgSO}_{4}$ or $\mathrm{MgCl}_{2}$

\begin{tabular}{|c|c|c|c|c|c|c|}
\hline \multirow[b]{3}{*}{$\underset{I}{\text { Subject no }}$} & \multirow[b]{3}{*}{$\begin{array}{c}\text { Infusion } \\
\mathrm{MgSO}_{4} \\
\mathrm{MgCl}_{2}\end{array}$} & \multicolumn{5}{|c|}{ Mg excreted } \\
\hline & & \multicolumn{3}{|c|}{ m-equiv. } & \multicolumn{2}{|c|}{ As percentage of dose } \\
\hline & & $\begin{array}{c}24 \mathrm{~h} \text { before } \\
\text { I I } 4 \\
\text { IO } \cdot 1\end{array}$ & $\begin{array}{c}24 \mathrm{~h} \text { after } \\
58.6 \\
67.5\end{array}$ & $\begin{array}{c}48 \mathrm{~h} \text { after } \\
69^{\circ} \cdot 4 \\
79^{\circ} 6\end{array}$ & $\begin{array}{c}24 \mathrm{~h} \text { after } \\
70 \cdot 0 \\
80 \cdot 5\end{array}$ & $\begin{array}{c}48 \mathrm{~h} \text { after } \\
82 \cdot 5 \\
94.7\end{array}$ \\
\hline 2 & $\mathrm{MgSO}_{4}$ & $7 \cdot 0$ & - & $99 \cdot 8$ & - & I 18 \\
\hline & $\mathrm{MgCl}_{2}$ & $5 \cdot 1$ & $62 \cdot 2$ & $72 \cdot 6$ & $74^{\circ} \circ$ & $86 \cdot 5$ \\
\hline 3 & $\mathrm{MgSO}_{4}$ & - & 60.5 & $75 \cdot 2$ & $72 \cdot 0$ & $89^{\circ} 5$ \\
\hline
\end{tabular}

Table 3. Urinary excretion of magnesium by patients with steatorrhoea in the $24 \mathrm{~h}$ and $48 \mathrm{~h}$ after an infusion of $84 \mathrm{~m}$-equiv. $\mathrm{Mg}$ as $\mathrm{MgSO}_{4}$ or $\mathrm{MgCl}_{2}$

\begin{tabular}{|c|c|c|c|c|c|c|}
\hline \multirow{5}{*}{$\begin{array}{l}\text { Patient } \\
\text { I (J.R.) } \\
2 \text { (R.B.) }\end{array}$} & \multirow{3}{*}{$\begin{array}{c}\text { Infusion } \\
\mathrm{MgSO}_{4}\end{array}$} & \multicolumn{5}{|c|}{$\mathrm{Mg}$ excreted } \\
\hline & & $24 \mathrm{~h}$ before & $24 \mathrm{~h}$ after & $48 \mathrm{~h}$ after & $24 \mathrm{~h}$ after & $48 \mathrm{~h}$ after \\
\hline & & o & 17.87 & $18 \cdot 47$ & $2 \mathrm{I} \cdot 2$ & $22 \cdot 0$ \\
\hline & $\mathrm{MgSO}_{4}$ & I'5 & $3 I \cdot 4$ & $33 \cdot 6$ & $37 \cdot 4$ & $40 \cdot 0$ \\
\hline & $\mathrm{MgCl}_{2}$ & $2 \cdot 2$ & $29 \cdot 4$ & $38 \cdot 8$ & $35^{\circ} \circ$ & $46 \cdot 2$ \\
\hline \multirow[t]{2}{*}{3 (A.P.) } & $\mathrm{MgSO}_{4}$ & 0.65 & $17 \cdot 28$ & 20.48 & $20 \cdot 6$ & $24 \cdot 4$ \\
\hline & $\mathrm{MgCl}_{2}$ & 0.82 & $2 \cdot 0$ & $2 \cdot 9$ & $2 \cdot 3^{8}$ & 3.46 \\
\hline \multirow[t]{2}{*}{4 (G.S.) } & $\mathrm{MgSO}_{4}$ & 10.5 & $52 \cdot 9$ & $62 \cdot 8$ & $63 \cdot 0$ & $74 \cdot 8$ \\
\hline & $\mathrm{MgCl}_{2}$ & 4.0 & $23 \cdot 8$ & $32 \cdot 6$ & $27 \cdot 4$ & $38 \cdot 8$ \\
\hline
\end{tabular}


The normal persons excreted more than $80 \%$ of the injected $\mathrm{Mg}$ in $4^{8} \mathrm{~h}$. The patients with steatorrhoea all excreted much less than that.

Fig. I shows the rate of excretion of $\mathrm{Mg}$ on the day of the intravenous infusions in the normal persons. The cumulative percentage of the total daily excretion of creatinine excreted with successive urine collections is shown on the abscissa and serves as a measure of time. The percentage of the infused Mg excreted is shown on the ordinate. The excretion of $\mathrm{Mg}$ increased rapidly in the first quarter of the day and then rose slowly to its value at the end of the $24 \mathrm{~h}$ period.
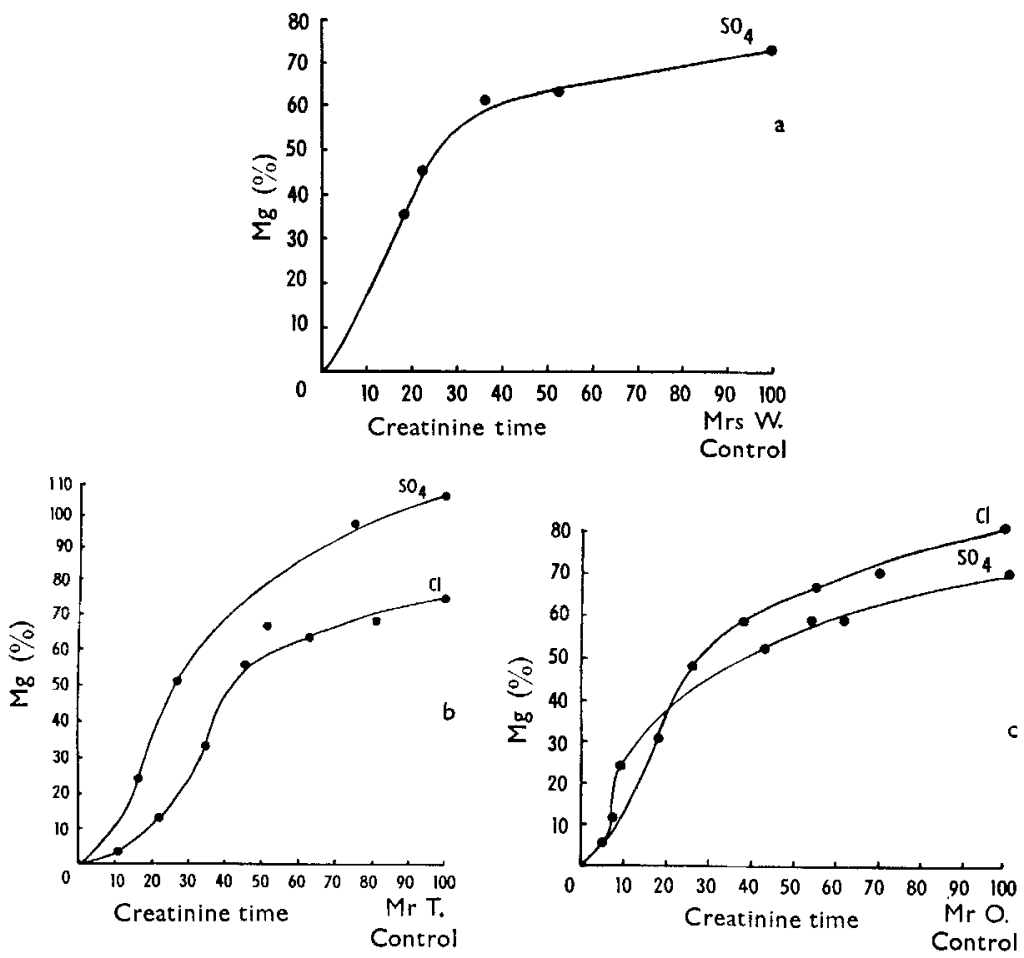

Fig. I. Rate of excretion of magnesium on the day of its intravenous infusion into normal persons. The cumulative percentage of the total creatinine excreted in successive urine specimens during the day is shown on the abscissa, and serves as a measure of time. The percentage of the injected $\mathrm{Mg}$ excreted is shown on the ordinate. $\mathrm{SO}_{4}, \mathrm{Mg}$ infused as $\mathrm{MgSO}_{4} ; \mathrm{Cl}, \mathrm{Mg}$ infused as $\mathrm{MgCl}_{2}$.

Fig. 2 shows the rate of $\mathrm{Mg}$ excretion in the four patients. It will be seen that the excretion of $\mathrm{Mg}$ increased less rapidly in the patients than in the normal persons.

Patient no. I was studied three times (Fig. 2a). He increased his excretion of $\mathrm{Mg}$ more quickly after he had retained 132 m-equiv. $\mathrm{Mg}$. 

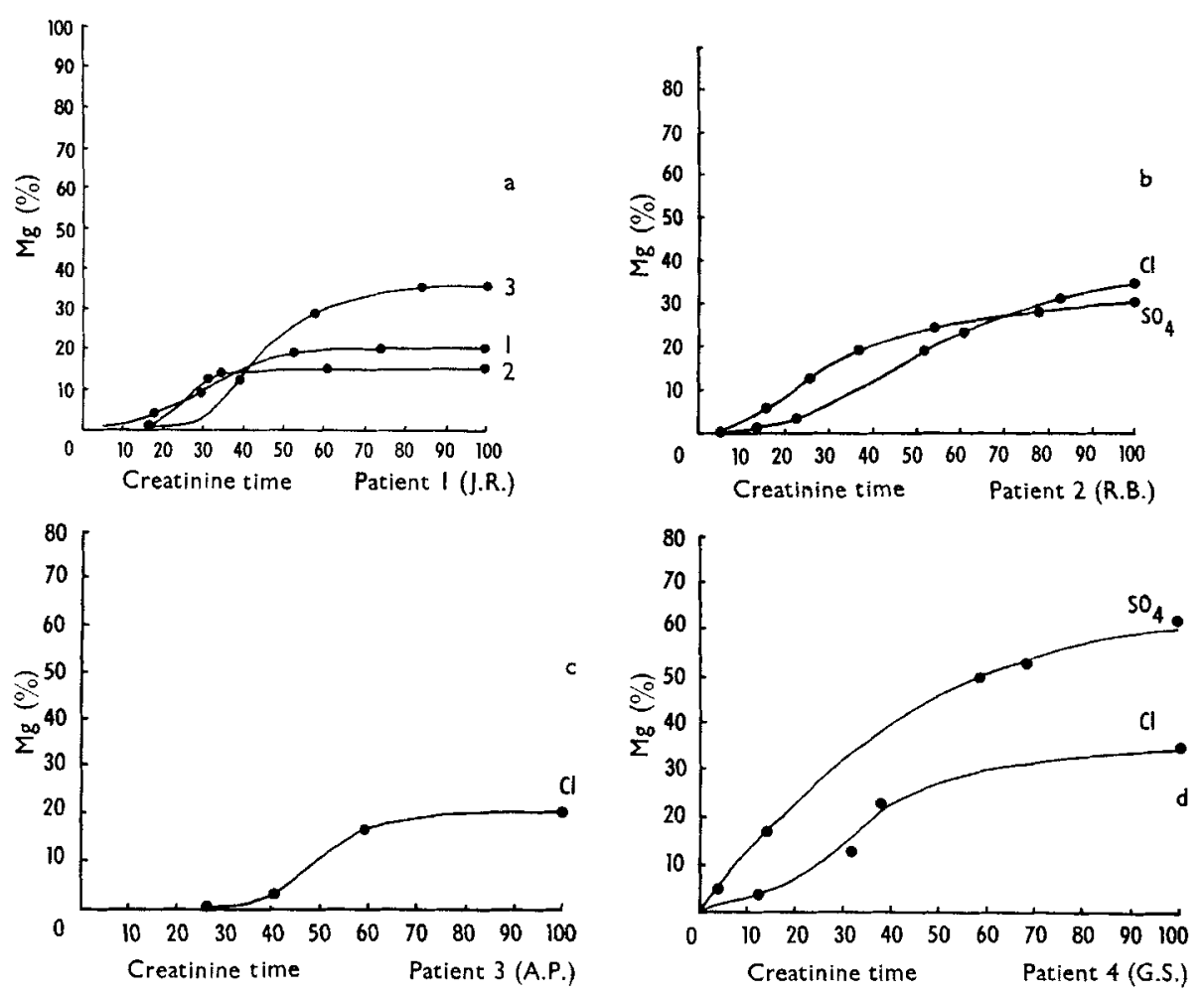

Fig. 2. Rate of excretion of magnesium on the day of its infusion in four patients with steatorrhoea. For explanation see Fig. r. With patient J.R. the excretion was studied three times after infusions of $\mathrm{MgSO}_{4}$.

Repeated injections of $M g$. The second part of the investigation was designed to measure the total $\mathrm{Mg}$ deficit. Fig. $3^{\mathrm{a}}$ shows the urinary excretion of $\mathrm{Mg}$ in patient no. I during 83 days when he had thirty-one injections and a total of 1428 m-equiv. Mg. During this period he excreted only $970 \mathrm{~m}$-equiv. $\mathrm{Mg}$ in the urine, apparently retaining $460 \mathrm{~m}$-equiv. The cumulative retention of $\mathrm{Mg}$ is shown in the upper half of Fig. 3a. The lower half of the figure shows the Mg excretion from day to day. The amount retained after each injection decreased progressively over the period of 80 days.

'The calculated deficit of $460 \mathrm{~m}$-equiv. in patient no. I involves the assumption that $\mathrm{Mg}$ given parenterally is excreted only through the kidneys (see Table 2) and that the small amount of $\mathrm{Mg}$ absorbed from the diet can be neglected. It can be seen from Fig. 3 a that the urinary excretion of $\mathrm{Mg}$ was very small on days when the patient was not given an injection. Fig. $3 \mathrm{~b}, \mathrm{c}, \mathrm{d}$ shows the successive changes in $\mathrm{Mg}$ excretion after its injection in patients nos. 2, 3 and 4. Fig. $3 \mathrm{~b}, \mathrm{c}$ also shows the accumulated retention of $\mathrm{Mg}$ in patients nos. 2 and 3 . They retained 460 and 440 m-equiv. in 60 and 40 days. The values for patient 4 were incomplete. 

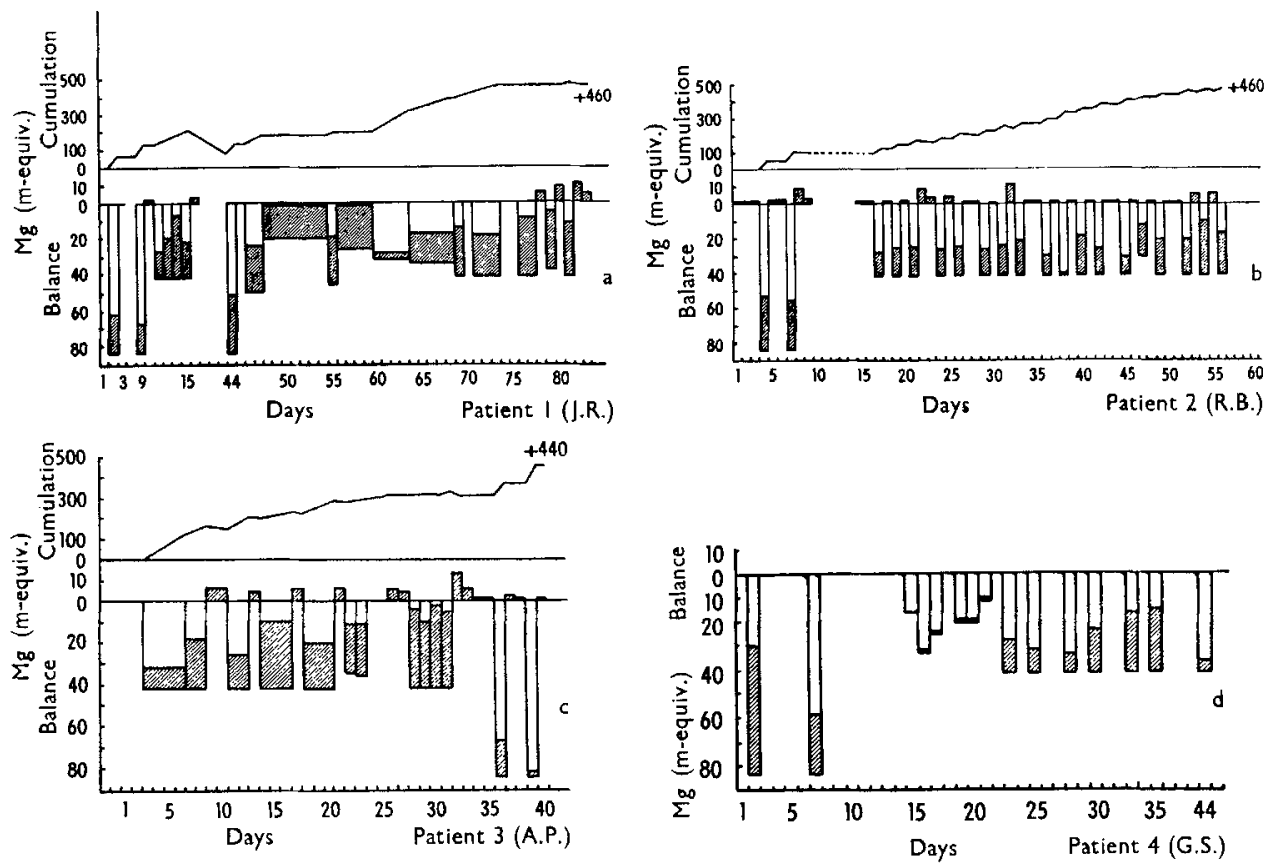

Fig. 3. The lower part of each chart shows the urinary excretion of magnesium from day to day in four patients with steatorrhoea while they were receiving injections of $\mathrm{Mg}$ as the sulphate. The amount of $\mathrm{Mg}$ injected is plotted downwards from the zero line. The excretion of $\mathbf{M g}$ is plotted upwards from the apparent intake, assumed to be zero on the days when the patient had no injection. The difference between the amount injected and the amount excreted, shown as a clear area on the chart, represents $\mathrm{Mg}$ retained. The amount retained after each injection fell steadily. The upper part of the charts for patients J.R., R.B. and A.P. shows the calculated cumulative gain of Mg. Information about patient G.S. is incomplete.

\section{Discussion}

The large deficits of $\mathrm{Mg}$ in these patients were entirely unexpected. They were not associated with the recognized symptoms of $\mathrm{Mg}$ deficiency or with a low plasma $\mathrm{Mg}$, but two of the patients felt a considerable gain of muscular strength when their deficit was corrected. One of the patients (J.R.) had a persistently low plasma Ca content and intractable tetany. His plasma Ca content rose and his tetany remitted.

The problem of the fate of the injected $\mathrm{Mg}$ has not been investigated. $\mathrm{Mg}$ depletion in growing animals affects entirely the fraction in bone (Cunningham, r933; Orent, Kruse \& McCollum, 1934; Tufts \& Greenberg, I937-8; Watchorn \& McCance, 1937; Duckworth, Godden \& Warnock, I940; Blaxter, Rook \& McDonald, I954; Smith, 1959a,b), but in older animals and in man Mg deficiency may affect also the soft tissues, and in particular the muscle (MacIntyre \& Davidsson, I958; McAleese \& Forbes, I961; MacIntyre, Hanna, Booth \& Read, I96I). The problem can only be 
investigated by the analysis of samples of muscle and bone, but it is worth while at this stage to draw attention to a possible difference between the composition of bone in steatorrhoea and bone in rickets or osteomalacia caused by simple deficiency of vitamin $\mathrm{D}$. In classical rickets the $\mathrm{Mg}$ content of bone increases, partly replacing the deficit of calcium. Our results suggest that in osteomalacia caused by steatorrhoea $\mathrm{Mg}$ may not be available to replace calcium in bone.

\section{REFERENCES}

Anonymous. (1960). Nutr. Rev. 18, 72.

Barney, J. D. \& Sulkowitch, H. W. (1937). F. Urol. 37, 746.

Baron, D. N. (1 960), Brit. F. Surg. 48, 344.

Blaxter, K. L., Rook, J. A. F. \& McDonald, A. M. (1954). F. comp. Path. 64, 157.

Card, W. I. \& Marks, I. N. (1958). Ciba Fdn Colloquia on Ageing, 4, 301.

Clough, P. W. (1960). Ann. intern. Med. 53, 615.

Cope, M. \& Barnes, B. (1960). Ann. Surg. 152, 518.

Cunningham, I. J. (1933). N.Z.F. Sci. Tech. I5, I9I.

Duckworth, J., Godden, W. \& Warnock, G. M. (r940). Biochem. Y. 34, 97.

Eliel, L. P., Smith, W. O. \& Thomsen, C. (1960). F. Okla. med. Ass. 53, 359.

Fales, F. W. \& Paubionsky, P. (1958). In Standard Methods of Clinical Chemistry, Vol. 2, p. I. [D. Seligson, editor.] New York: Academic Press Inc.

FitzGerald, M. G. \& Fourman, P. (1956). Clin. Sci. 15, 635 .

Fletcher, R. F., Henly, H. A., Sammons, H. G. \& Squire, J. R. (I960). Lancet, i, 522.

Flink, E. B., McCollister, R., Prasad, A. S., Melby, J. C. \& Doe, R. P. (1957). Ann. intern. Med. 47, 956 .

Flink, E. B., Stutzman, F. L., Anderson, A. R., Konig, T. \& Fraser, R. (1954). F. Lab. clin. Med. 43, I69.

Frankenhaeuser, B. \& Meves, H. (1958). F. Physiol. r42, 360.

Garner, R. J. (1946). Biochem. F. 40, 828 .

Grantham, J. J., Tu, W. H. \& Schloerb, P. R. (1960). Amer. F. Physiol. 198, 121 1.

Hammarsten, J. F. \& Smith, W. O. (1957). New Engl. F. Med. 256, 897.

Hanna, S., Harrison, M., MacIntyre, I. \& Fraser, R. (1960). Lancet, ii, 172.

Hanna, S. \& MacIntyre, I. (r960). Lancet, ii, 348.

Hirschfelder, A. D. \& Haury, V. G. (1934). F. Amer. med. Ass. 102, 1138.

King, E. J. \& Armstrong, A. R. (I934). Canad. med. Ass. F. 31, 376.

Kingsley, G. R., Schaffert, R. R. \& Reiner, M. (1953). In Standard Methods of Clinical Chemistry, Vol. I, p. 55. [M. Reiner, cditor.] New York: Academic Press Inc.

McAleese, D. M. \& Forbes, R. M. (1961). F. Nutr. 73, 94.

McCance, R. A. \& Widdowson, E. M. (1939). Biochem. F. 33, 523.

McCollister, R. J., Flink, E. B. \& Doe, R. P. (1960). F. Lab. clin. Med. 55, 98.

MacIntyre, I. \& Davidsson, D. (1958). Biochem. $\mathcal{F} .70,456$.

MacIntyre, I., Hanna, S., Booth, C. C. \& Read, A. E. (1961). Clin. Sci. 20, 297.

Mendel, L. B. \& Benedict, S. R. (1909). Amer. F. Physiol. 25, I.

Miller, J. F. (1 944). Amer. F. Dis. Child. 67, 117.

Nicolaysen, R. (r936). Skand. Arch. Physiol. 73, 75 .

Orent, E. R., Kruse, H. D. \& McCollum, E. V. (1934). F. biol. Chem. xo6, 573.

Pritchard, J. A. (1955). Surg. Gynec. Obstet. roo, I3I.

Randall, R. E., Rossmeisl, E. C. \& Bleifer, K. H. (1959). Ann. intern. Med. 50, 257.

Smith, P. K., Winkler, A. W. \& Schwartz, B. M. (1939). J. biol. Chem. 129, 5 I.

Smith, R. H. (1959a). Biochem. J. 7I, 306.

Smith, R. H. (1959b). Biochem. F. 71, 609.

Suter, C. \& Klingman, W. D. (1955). Neurology, ro, 69 I.

Tibbetts, D. M. \& Aub, J. C. (1937). F. clin. Invest. 16, 5 I r.

Tufts, E. V. \& Greenberg, D. M. (1937-8). F. biol. Chem. 122, 693.

Vallee, B. C., Wacker, W. E. C. \& Ulmer, D. D. (1960). New Engl. F. Med. 262, 155.

Watchorn, E. \& McCance, R. A. (1937). Biochem. F. 31, I379.

Wilkinson, R. H. (1960). Chemical Micromethods in Clinical Medicine, p. 88. Oxford: Blackwell Scientific Publications.

Womersley, R. A. (1958). F. Physiol. 143, 300. 